\title{
ANALISIS RASIONALITAS INVSETOR DALAM PEMILIHAN DAN PENENTUAN PORTOFOLIO OPTIMAL PADA SAHAM-SAHAM JAKARTA ISLAMIC INDEX
}

\author{
Raden Arfan Rifqiawan ${ }^{1}$
}

\begin{abstract}
The purpose of this study is to determine that wether investor rationality exist in undergoing the stock choice in Jakarta Islamic Index at Indonesia Stock Exchange. Population to be chosen in the study is 44 firms listed on JII. However, the sample included are only 19 firms that present 30 times consecutively of simultan monitoring on JII. From 19 firms after analyzed with single index model found 11 has firms has $E R B>C i^{*}$, that mean if investor invests in 11 stocks will get return higher with lower risk in comparison with investment in risk free asset. Data to be used in the study is the secondary one, which is collected from Indonesia Stock Exchange Monthly Statistic and risk free rate report from Central Bank of Indonesia.Result to be obtained from the study demonstrates on empirical evidence of investor rationally in choosing the stock on JII. The value is showed averagely stocks trade volume that has ERB >Ci* higher is compared averagely stocks trade volume that has $E R B<C i *$.
\end{abstract}

Keywords : Return, Risk Free Return, Optimal Portfolio, Excess return to Beta, Jakarta Islamic Index (JII).

\section{PENDAHULUAN}

Peran pasar modal sebagai wahana alternatif bagi investor dipengaruhi oleh banyak faktor. Salah satu faktor yang menetukan adalah tingkat kemampuan investor memilih saham secara rasional ${ }^{2}$. Rasionalitas investor dapat diukur dari sejauh mana mereka berhasil memilih saham yang memberi hasil maksimum pada risiko tertentu, juga dipengaruhi oleh preferensi investor terhadap return dan risiko yang berbeda. Investor akan selalu mencoba mencari portofolio yang memberikan return maksimum untuk risiko tertentu, atau return tertentu dengan risiko minimum.

Pada praktiknya investor sering melakukan diversifikasi dalam investasinya. Mereka mengkombinasikan berbagai sekuritas dalam investasi mereka. Dengan kata lain, para investor membentuk portofolio. Portofolio adalah sekumpulan kesempatan investasi. Investor melakukan diversifikasi ini untuk mengurangi risiko ${ }^{3}$. Poon, Taylor dan Ward melalui studi empirisnya dengan menggunakan analisis pictorial, menarik kesimpulan bahwa diversifikasi

\footnotetext{
${ }^{1}$ Penulis adalah dosen Fakultas Syari'ah IAIN Walisongo Semarang

E-mail : Raden Arfan Rifqiawan <den_rifqi@yahoo.co.id

${ }^{2}$ Said Bawazier dan Sitanggang, Memilih Saham-Saham untuk Portofolio Optimal, Jurnal Usahawan Vol. XI, hal 34-40. Januari 1994.

${ }^{3}$ Suad Husnan, Dasar-dasar Teori Portofol, Yogyakarta : UPP AMP YKPN, 2001, hal 17.
} 
saham melalui simulasi mampu memperkecil tingkat risiko dan mencapai return maksimal ${ }^{4}$. Uji coba dilakukan dengan menggunakan 10, 25, 50 sampai 100 saham untuk membentuk portofolio. Sedangkan Bringham dan Gapenski memilih portofolio efisien dari portofolio yang terletak pada efficient frontier ${ }^{5}$.

Untuk menganalisis portofolio, diperlukan sejumlah prosedur perhitungan melalui sejumlah data sebagai input tentang struktur portofolio. Salah satu teknik portofolio optimal yang dilakukan oleh Elton dan Gruber, adalah menggunakan indeks tunggal ${ }^{6}$. Model indeks tunggal merupakan penyederhanaan dari perhitungan portofolio model Markowitz. Analisis atas sekuritas dilakukan dengan membandingkan excess return to beta (ERB) dengan cut-off rate-nya $(\mathrm{Ci})$ dari masing-masing saham. Saham yang memiliki ERB lebih besar dari $\mathrm{Ci}$ dijadikan kandidat portofolio, sedang bila sebaliknya yaitu $\mathrm{Ci}$ lebih besar dari ERB tidak diikutkan dalam portofolio. Dengan kata lain portofolio yang optimal akan berisi dengan saham-saham yang mempunyai ERB yang tinggi. Saham-saham dengan ERB yang rendah tidak akan dimasukkan ke dalam portofolio yang optimal. $\mathrm{Ci}$ itu sendiri merupakan pembatas yang menentukan batas nilai ERB berapa yang dikatakan tinggi. Pemilihan saham dan penentuan portofolio optimal yang dilakukannya tersebut didasari oleh pendahulunya Markowitz yang dimulai dari data historis atas saham individual yang dijadikan input, dan dianalisis untuk menghasilkan sejumlah keluaran yang menggambarkan kinerja dari setiap portofolio, apakah tergolong portofolio yang baik, atau sebaliknya ${ }^{7}$.

Rasionalitas investor diukur dari sejauh mana investor melakukan prosedur pemilihan saham dan penentuan portofolio optimal dari data historis pada saham-saham yang listed di Bursa Efek. Permasalahan ini dapat dijawab melalui dua pendekatan, pertama dengan melakukan penghitungan untuk memilih saham dan menentukan portofolio optimal dengan model indeks tunggal, kedua dengan pola perilaku investor di bursa yang tercermin dari aktivitasnya melakukan transaksi jual beli saham pada saham-saham yang diikutkan dalam portofolio ${ }^{8}$.

Penelitian yang dilakukan oleh R. Agus Sartono dan Sri Zulaihati mengenai rasionalitas investor terhadap pemilih saham-saham yang tergabung dalam ILQ-45 dilakukan dengan menguji perbedaan rata-rata volume perdagangan saham-saham yang memiliki nilai $\mathrm{ERB}>\mathrm{Ci}^{*}$ dengan rata-rata volume perdagangan saham-saham yang memiliki nilai ERB < $\mathrm{Ci}^{*}$. Hasil penelitiannya disimpulkan investor cukup rasional dalam melakukan transaksi perdagangan di BEJ, karena rata-rata volume perdagangan saham dari saham-saham yang memiliki nilai ERB > $\mathrm{Ci}^{*}$ berbeda secara signifikan dengan rata-rata volume perdagangan saham-saham yang memiliki ERB < Ci*. Namun saham yang masuk sebagai faktor penghitung ILQ-45 belum menjamin tercapainya harapan investor akan perolehan return yang diinginkannya karena investasi pada kombinasi saham yang masuk sebagai faktor penghitung ILQ-45 akan memberikan return portofolio sebesar 2,73\% dengan risiko ( $\beta \mathrm{p}$ ) sebesar $271,38 \%$.

Peneliti tertarik menguji perbedaan rata-rata volume perdagangan saham-saham yang memiliki nilai $\mathrm{ERB}>\mathrm{Ci}$ * dengan rata-rata volume perdagangan saham-saham yang memiliki

\footnotetext{
${ }^{4}$ S Poon, S.J. Taylor dan C.W.R. Ward (1992), Portofolio Diversification: A Pictorial Analysis of the U.K. Stock Market, Journal of Business Finance and Accounting, 1992, hal. 87-101

${ }^{5}$ F. Eugene Bringham dan Gapenski C. Louis, Intermediate Financial Management, New York: Harcourt Brace College, 1993, hal 83-84.

${ }^{6}$ J. Edwin Elton, dan J Martin Gruber, Modern Portofolio Theory and The Investment Analisys. New York.: John Wiley \& Sons. Inc. 1995, hal.44

${ }^{7}$ M. Harry Markowitz, Portofolio Security : Efficient Diversification of Investment, New York: John Wiley \& Sons. Inc., 1959, hal 138-148

8 R. Agus Sartono \& Sri Zulaihati, Rasionalitas Investor Terhadap Pemilihan dan Penentuan Portafolio Optimal Dengan Model Indeks Tunggal di BEJ. Kelola No. 17/VII/1998, hal 22-23.

${ }^{9}$ ibid
} 
nilai ERB $<\mathrm{Ci}^{*}$ pada saham-saham yang tergabung pada Jakarta Islamic Index (JII) di BEJ (sekarang namanya berubah menjadi Bursa Efek Indonesia (BEI)) karena dengan mengetahui perbedaan rata-rata volume perdagangan saham-saham yang efisien dan yang tidak efisien dapat diketahui pola perilaku investor dalam membeli saham, apakah rasional atau tidak. Selain itu saat ini BEI terus melakukan berbagai upaya pengenalan produk-produk syari'ah di pasar modal. Bahkan bersama dengan Bapepam dan Dewan Syari'ah Nasional, tengah mengupayakan rangsangan bagi penciptaan produk-produk investasi yang berbasis syari'ah. Selain sebagai upaya memperbesar basis investor, upaya merangsang, terciptanya produkproduk syari'ah di pasar modal sebagai antisipasi trend investasi dewasa ini.

Dalam konteks saham, di pasar modal Indonesia sudah dikenal sejumlah saham yang berbasis syari'ah, saham-saham tersebut tergabung dalam Jakarta Islamic Index (JII). Di BEI, JII saat ini jumlahnya mencapai 30 emiten. Ke-30 emiten ini merupakan emiten yang oleh BEI dinilai memenuhi persyaratan syari'ah, sehingga JII ini menjadi patokan bagi manajer investasi dalam berinvestasi untuk saham.

Berdasarkan uraian diatas, masalah yang diuji dalam penelitian ini adalah: Apakah terdapat perbedaan yang signifikan antara rata-rata volume perdagangan saham-saham yang memiliki nilai ERB $>\mathrm{Ci}^{*}$ dengan rata-rata volume perdagangan saham-saham yang memiliki nilai ERB < Ci* pada saham-saham yang tergabung dalam Jakarta Isamic Index di Bursa Efek Indonesia". Sebagaimana permasalahan yang dikemukakan di atas, maka penelitian ini bertujuan untuk menentukan ada tidaknya perbedaan yang signifikan antara rata-rata volume perdagangan saham-saham yang memiliki nilai $\mathrm{ERB}>\mathrm{Ci}^{*}$ dengan rata-rata volume perdagangan saham-saham yang memiliki nilai ERB $<\mathrm{Ci}^{*}$ pada saham-saham yang tergabung dalam Jakarta Islamic Index di Bursa Efek Indonesia”.

\section{TELAAH TEORITIS}

Investor yang rasional akan menginvestasikan dananya dengan memilih saham yang efisien, yang memberikan return maksimal dengan risiko tertentu, atau return tertentu dengan risiko minimal. Untuk menghindari atau memperkecil risiko, investor melakukan strategi diversifikasi atas investasinya dengan membentuk portofolio yang terdiri atas beberapa saham yang dinilai efisien.

Menurut Sharpe, Alexender dan Bailey, portofolio dikategorikan efisien apabila memiliki tingkat risiko yang sama, mampu memberikan tingkat keuntungan yang lebih tinggi, atau mampu menghasilkan tingkat keuntungan yang sama, tetapi dengan risiko yang lebih rendah $^{10}$.

Untuk menghitung portofolio efisien dapat dilakukan dengan model sebagaimana dikutip oleh Akhmad Fauzi dkk, sebagai berikut ${ }^{11}$ :

\section{Model Markowitz.}

Dalam model Markowitz tingkat keuntungan yang diharapkan dari suatu portofolio merupakan rata-rata tertimbang dari tingkat keuntungan yang diharapkan dari saham-saham yang membentuk portofolio tersebut, yang dinyatakan dalam rumus:

$$
\mathrm{E}(\mathrm{Rp})=\sum_{\mathrm{i}=1}^{\mathrm{N}} \mathrm{Xi} \mathrm{E}(\mathrm{Ri})
$$

dimana,

${ }^{10}$ Sharpe R. William F. Gordon J. Alexender, dan Jeffry V. Bailey, Investment. New York : Prentice Hall., 1963, hal 49-58

${ }^{11}$ Akhmad Fauzi, Johan Arifin, dan M. Fakhrudin, Aplikasi Excel dalam Finansial Terapan, Jakarta: PT. Elex media Komputindo, 2004, hal 48 
$\mathrm{E}(\mathrm{Rp})=\quad$ tingkat keuntungan yang diharapkan dari portofolio

$\mathrm{Xi}=$ proporsi dana yang diinvestasikan pada saham $\mathrm{i}(\mathrm{i}, \ldots \mathrm{N})$

$\mathrm{E}(\mathrm{Ri})=$ tingkat keuntungan yang diharapkan dari saham $\mathrm{i}$

Untuk variance portofolio dihitung dengan rumus:

$$
\sigma_{p}^{2}=\sum_{i=1}^{N} X_{i}^{2} \sigma_{i}^{2}+\sum_{i=1}^{N} \sum_{j=1}^{N} X i X j \delta i j
$$

dimana,

$$
\begin{array}{lll}
\sigma_{\mathrm{p}}^{2} & = & \text { variance } \text { portofolio } \\
\sigma_{\mathrm{i}}^{2} & = & \text { variance } \text { saham } \mathrm{i}(\mathrm{i}, \ldots \mathrm{N} ; \text { dan } \mathrm{i} \neq \mathrm{j}) \\
\delta \mathrm{ij} & =\begin{array}{l}
\text { covariance } \text { saham } \mathrm{i} \text { dengan saham } \mathrm{j} \text { yang merupakan perkalian } \\
\text { antara korelasi saham } \mathrm{i} \text { dan } \mathrm{j} \text { dengan deviasi saham } \mathrm{i} \text { dan } \mathrm{j} .
\end{array}
\end{array}
$$

\section{Model Indeks Tunggal}

Tujuan penggunaan model indeks tunggal adalah untuk menyederhanakan perhitungan portofolio model Markowitz. Pada portofolio model Markowitz dibutuhkan parameterparameter input berupa: (1) Tingkat keuntungan yang diharapkan masing-masing saham/sekuritas, (2) Variance masing-masing saham/sekuritas dan (3) Covariance antara saham-saham/sekuritas-sekuritas

Seandainya kita akan melakukan analisis suatu portofolio yang terdiri dari sepuluh saham (model Markowitz) maka untuk menaksir return portofolio kita perlu menaksir sepuluh tingkat keuntungan saham/sekuritas. Untuk menaksir risiko portofolio kita perlu menaksir sepuluh variance tingkat keuntungan dan empat puluh lima covariance yang didapat dari rumus $[\mathrm{n}(\mathrm{n}-1)] / 2$ atau $[10(10-1)] / 2=45$. Total parameter yang harus dihitung berjumlah 55 .

Dengan model indeks tunggal, menaksir variance tingkat keuntungan portofoio hanya membutuhkan $(2 n+1)$, sehingga jumlah parameter yang dihitung hanya berjumlah 21 . Baik model Markowitz maupun model indeks tunggal menghasilkan nilai yang sama dalam menghitung return dan risiko portofolio ${ }^{12}$.

Dalam model indeks tunggal, Elton dan Gruber mengukur portofolio efisien dengan ukuran theta $(\theta)$ dengan formula berikut ${ }^{13}$ :

$$
\theta=\frac{\overline{\mathrm{Rp}}-\mathrm{Rf}}{\sigma}
$$

dimana,

$$
\begin{array}{lll}
\mathrm{Rp} & = & \text { return portofolio } \\
\mathrm{Rf} & = & \text { riskfree } \\
\sigma & = & \text { covariance portofolio }
\end{array}
$$

Untuk memperoleh nilai theta $(\theta)$ diperlukan menghitung return portofolio dengan formula berikut:

$$
\overline{\mathrm{Rp}}=\sum_{\mathrm{i}=1}^{\mathrm{N}} \mathrm{Xi} \quad \overline{\mathrm{Ri}}
$$

dimana,

$$
\mathrm{Xi} \quad=\quad \text { proporsi investasi pada saham } \mathrm{i}
$$

\footnotetext{
${ }^{12}$ Ibid

${ }^{13}$ Elton, J. Edwin, dan J Martin Gruber. 1995. Op.cit hal 60
} 


$$
\mathrm{Ri} \quad=\quad \text { rata-rata return saham } \mathrm{i}
$$

Dan menghitung covariance portofolio dengan formula berikut:

dimana,

$$
\sigma \mathrm{p}=\beta \mathrm{p} \quad \sigma \mathrm{m}
$$

$$
\begin{array}{rll}
\beta \mathrm{p} & =\text { beta portofolio } \\
\sigma \mathrm{m} & =\quad \text { covariance pasar }
\end{array}
$$

sedang beta portofolio dihitung dengan menggunakan formula berikut ini:

$$
\beta p=\sum X i{ }_{i=1} \underset{i}{N}
$$

dimana:

$\beta \mathrm{i}=$ beta saham $\mathrm{i}$

Ukuran portofolio efisien tidak terlepas dari unsur return dari risiko, maka perhitungan secara matematis diperlukan untuk mengukurnya. Van Horne menyatakan, bahwa investor yang menginvestasikan dananya dalam suatu portofolio pada periode tertentu, maka investor akan menerima pembayaran kas melalui deviden kas, juga dari perubahan harga saham yang terjadi di bursa, baik berupa capital gain (selisih lebih antara harga beli dan harga jual). Return pada periode $\mathrm{t}$ (Rit) dihitung dengan menggunakan formula berikut ${ }^{14}$ :

$$
\mathrm{Dt}+(\mathrm{Pt}-\mathrm{Pt}-1)
$$

$$
\text { Ri }=\frac{}{\text { Pt-1 }}
$$

dimana:

$$
\begin{array}{lll}
\mathrm{Dt} & = & \text { deviden pada periode } \mathrm{t} \\
\mathrm{Pt} & = & \text { harga saham pada periode } \mathrm{t} \\
\mathrm{Pt}-1 & = & \text { harga saham pada periode } \mathrm{t}-1
\end{array}
$$

Untuk menghitung risiko ( $\beta \mathrm{i})$, Elton dan Gruber menggunakan pendekatan pasar atau model indeks tunggal dengan persamaan berikut ${ }^{15}$ :

dimana:

$$
\text { Rit }=\alpha i+\beta i R m t+e i t
$$

$$
\begin{array}{lll}
\mathrm{Rit} & = & \text { return saham pada periode } \mathrm{t} \\
\alpha \mathrm{i} & = & \begin{array}{l}
\text { intercept } \text { yang merupakan suatu konstanta atau nilai yang tidak } \\
\text { dipengaruhi oleh perubahan Rit maupun } \mathrm{Rmt}
\end{array} \\
\mathrm{Bi} & = & \begin{array}{l}
\text { beta saham yang merupakan ukuran sensitivitas Ri terhadap } \mathrm{Rm} \\
\text { residual } \text { error } \text { saham I pada periode } \mathrm{t} \text { yang merupakan selisih }
\end{array} \\
\mathrm{eit} & =\begin{array}{l}
\text { antara } \text { it yang diharapkan dengan Rit riil } \\
\mathrm{Rmt}
\end{array}
\end{array}
$$

Untuk itu diperlukan menghitung return pasar (Rmt) dengan menggunakan kutipan dari Manurung ${ }^{16}$ dengan formula sebagai berikut:

$$
\text { Rmt }=\text { Ln }\left[\frac{\text { It }}{\text { It-1 }}\right]
$$

dimana:

\footnotetext{
${ }^{14}$ James C Van Horne \& John Wachowitz Jr., Financial Management and Policy, Englewood: Prentice Hall, 1992, hal. 35

${ }^{15}$ J. Edwin Elton dan J Martin Gruber, opcit hal 65

${ }^{16}$ Manurung, Adler Haymans, Kapitalisasi Besar, Kecil, dan Campuran, Jurnal Usahawan. No. 12 Th XXVI Des. 1997, hal 11
} 


$$
\begin{array}{lll}
\text { It } & = & \text { indeks pasar pada periode } \mathrm{t} \\
\mathrm{It}-1 & = & \text { indeks pasar pada periode } \mathrm{t}-1
\end{array}
$$

Atas dasar perhitungan return dan risiko saham $i$, investor dapat memilih saham mana yang masuk dalam batas efisien, untuk selanjutnya mendasari investor melakukan analisis lebih lanjut.

Prosedur penentuan portofolio optimal adalah model indeks tunggal. Telah dilakukan oleh Bawazier dan Sitanggang (1994) untuk membentuk portofolio optimal dengan membandingkan antara excess return to beta (ERB) yang merupakan kelebihan pengembalian atas tingkat keuntungan bebas risiko pada aset lain dan cut off rate (Ci). Cut off rate itu sendiri tidak lain adalah merupakan perbandingan antara varian return pasar dengan sensivitas return saham individu terhadap variance error saham. Saham-saham yang memiliki ERB lebih besar dari Ci dijadikan kandidat portofolio, sebaliknya bila ERB lebih kecil dari $\mathrm{Ci}$ tidak diikutkan dalam portofolio ${ }^{17}$. Pemilihan saham yang dilakukannya berdasarkan analisis fundamental, yaitu berdasarkan omzet penjualan, laba perusahaan, total aktiva dan laba per lembar saham terbesar pada tahun 1991 dari saham-saham yang listed di Bursa Efek Indonesia.

Prosedur perhitungan yang dilakukan berdasarkan rumusan Elton \& Gruber (1995) dengan mengurutkan saham-saham yang memiliki excess return to beta (ERB) tertinggi sampai terkecil. Hal ini dilakukan untuk mengetahui ranking saham-saham yang memiliki kelebihan return dari risk free pada aset lain, dengan asumsi saham tersebut tergolong sahamsaham yang efisien dengan formula berikut ${ }^{18}$ :

$$
\text { ERB }=\frac{\overline{R_{i}}-R_{f}}{\beta_{i}}
$$

dimana:

$$
\begin{array}{lll}
\overline{\mathrm{R}_{\mathrm{i}}} & = & \text { rata-rata return saham } \mathrm{i} \\
\mathrm{R}_{\mathrm{f}} & = & \text { risk free } \text { pada aset lain } \\
\beta_{\mathrm{i}} & = & \text { beta saham } \mathrm{i}
\end{array}
$$

Selanjutnya dibandingkan dengan cut off rate-nya (Ci) yang merupakan karakteristik saham individual adalah hasil bagi varians pasar terhadap pengembalian kelebihan lebih dari risk free pada aset lain terhadap variance error saham dengan varians pasar terhadap sensivitas saham individual terhadap variance error saham, dengan formula berikut:

$$
\mathrm{Ci}=\frac{\sigma_{\mathrm{m}}^{2} \sum \frac{\left(\overline{\mathrm{R}_{\mathrm{i}}}-\mathrm{R}_{\mathrm{f}}\right) \beta_{\mathrm{i}}}{\sigma_{\mathrm{ei}}^{2}}}{1+\sigma_{\mathrm{m}}^{2} \sum\left[\frac{\beta_{\mathrm{i}}^{2}}{\sigma_{\mathrm{ej}}^{2}}\right]}
$$

dimana:

$$
\begin{array}{lll}
\sigma_{e j}^{2} & = & \text { jumlah varians dari saham } i \\
\sigma_{\mathrm{m}}^{2} & = & \text { varians pasar }
\end{array}
$$

${ }^{17}$ Said Bawazier dan Sitanggang, Memilih Saham-Saham untuk Portofolio Optimal, Jurnal Usahawan No.1 Tahun XXIII Januari 1994, hal 34-40..

${ }^{18}$ J. Edwin Elton dan J Martin Gruber. Op.cit hal 71 


$$
\begin{array}{lll}
\beta_{i} & = & \text { jumlah beta saham } \\
\sigma_{\text {ej }}^{2}= & \text { jumlah varians dari residual error saham } \\
\beta_{i}^{2}= & \text { jumlah kuadrat beta saham }
\end{array}
$$

Untuk memperoleh variance residual error $\left(\sigma_{\mathrm{ej}}^{2}\right)$ saham $i$ dengan menggunakan formula sebagai berikut:

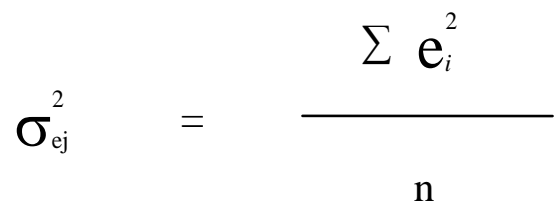

dimana:

$$
\begin{array}{lll}
\mathrm{e}_{\mathrm{i}}^{2} & = & \text { residual error } \text { dari saham } i \\
\mathrm{n} & = & \text { jumlah periode pengamatan }
\end{array}
$$

saham-saham yang memilki ERB yang lebih besar dari $\mathrm{Ci}$ - nya ditentukan untuk diikutkan dalam penentuan portofolio optimal dengan mendesain proporsi dana yang akan diinvestasikan pada masing-masing saham yang menjadi kandidat portofolio, dengan formula berikut:

$$
\mathrm{Xi}=\frac{\mathrm{Zi}}{\sum_{\text {Included }} \mathrm{Zj}}
$$

dimana:

$$
\begin{array}{lll}
\mathrm{Xi} & = & \text { prosentase dana yang akan diinvestasikan pada saham } \mathrm{i} \\
\mathrm{Zi} & = & \text { proporsi dana yang akan diinvestasikan pada saham } \mathrm{i} \\
\mathrm{Zj} & = & \text { totalitas dana yang akan diinvestasikan pada saham } \mathrm{i}
\end{array}
$$

Sedang untuk menghitung nilai $\mathrm{Zi}$ digunakan formula berikut:

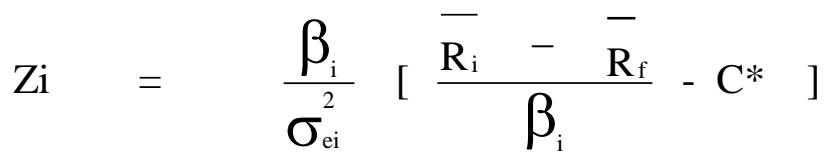

Dimana:

$$
\begin{array}{rll}
\mathrm{Zi} & = & \text { proporsi dana yang akan diinvestasikan pada saham } \mathrm{i} \\
\mathrm{Ri} & = & \text { rata-rata return saham } \mathrm{i} \\
\mathrm{Rf} & = & \text { risk free return pada aset lain } \\
\beta_{\mathrm{i}} & = & \text { beta saham } \mathrm{i} \\
\sigma_{\mathrm{ei}}^{2} & = & \text { variance residual } \text { error saham } \mathrm{i} \\
\mathrm{C}^{*} & = & \text { cut-off rate tertinggi }
\end{array}
$$

Dari dua perhitungan tersebut dapat diperoleh proporsi dana yang akan diinvestasikan pada masing-masing saham yang membentuk portofolio optimal.

\section{Rasionalitas Investor}

Investor yang rasional akan melakukan transaksi pada saham yang excess return to beta-nya lebih besar dari cut-off rate tertingginya, sedangkan investor yang irrasional akan 
melakukan transaksi pada saham yang excess return to beta-nya lebih kecil dibandingkan dengan cut-off rate tertingginya ${ }^{19}$.

Investor yang realistis menurut Mao akan melakukan investasi tidak hanya pada satu jenis investasi, akan tetapi melakukan diversifikasi pada berbagai investasi dengan pengharapan akan dapat meminimalkan risiko dan memaksimalkan return ${ }^{20}$. Strategi diversifikasi dilakukan dengan portofolio optimal yang berarti keuntungan diperoleh dengan diversifikasi pada berbagai investasi, dengan jumlah sekuritas tertentu yang memiliki return yang cukup tinggi. Portofolio optimal dicapai dengan melakukan simulasi pada beberapa sekuritas yang dinilai efisien dengan menggunakan prosedur perhitungan tertentu.

Kriteria pemilihan sekuritas atas dasar kinerja individu tidaklah tepat jika dikaitkan dengan kinerja portofolio. Meskipun merupakan rata-rata tertimbang return sekuritas secara individu, tetapi risiko yang perlu dipertimbangkan bukannya risiko rata-rata saja. Lebih dari itu harus diperhatikan pengaruh risiko individu terhadap risiko total. Pemilihan portofolio optimal juga akan dipengaruhi oleh preferensi investor atas risiko, dengan kata lain portofolio optimal akan merupakan keseimbangan antara excess return dan risiko total.

Trone dan Allbright menyatakan investor yang rasional melakukan keputusan investasi didasari dengan menganalisis situasi saat ini, mendesain portofolio optimal, menyusun kebijakan investasi, mengimplikasikan strategi investasi, memonitor dan melakukan supervisi pada kinerja khusus para manajer keuangan ${ }^{21}$.

Investor yang rasional akan melakukan langkah di atas dengan memantau pergerakan harga saham di bursa terus menerus, baik fluktuasi harian, mingguan, maupun bulanan, melakukan prosedur perhitungan memilih saham dan menentukan portofolio optimal, merencanakan investasi pada portofolio optimal, mengimplikasikan strategi investasi pada portofolio optimal, selanjutnya melakukan monitor secara berkala melalui fund manager yang ditunjuk dengan strategi tahan, jual, dan beli.

Tujuan penelitian dimaksudkan untuk menentukan ada tidaknya rasionalitas investor terhadap pemilihan saham-saham yang masuk dalam Jakarta Islamic Index (JII) yang tercermin dari volume perdagangan saham-saham yang diikutsertakan dalam penentuan portofolio optimal (sekelompok saham dengan nilai ERB untuk tiap saham individualnya > $\left.\mathrm{Ci}^{*}\right)$. Bila rata-rata volume perdagangan saham-saham yang masuk portofolio optimal lebih tinggi daripada rata-rata volume perdagangan saham-saham yang tidak masuk portofolio optimal, berarti terjadi rasionalitas investor dalam memilih saham dan membentuk portofolio optimal, sebaliknya bila rata-rata volume perdagangan saham-saham yang masuk portofolio optimal lebih rendah atau sama dengan rata-rata volume perdagangan saham-saham yang tidak masuk portofolio optimal, berarti tidak terjadi rasionalitas investor dalam memilih saham. Sehingga Hipotesis penelitian ini dirumuskan sebagai berikut :

Ho: Tidak ada perbedaan yang signifikan antara rata-rata volume perdagangan sahamsaham yang memiliki nilai ERB $>\mathrm{Ci}^{*}$ dengan rata-rata volume perdagangan sahamsaham yang memiliki nilai ERB $<\mathrm{Ci}^{*}$.

H1 : Ada perbedaan yang signifikan antara rata-rata volume perdagangan saham-saham yang memiliki nilai $\mathrm{ERB}>\mathrm{Ci}^{*}$ dengan rata-rata volume perdagangan saham-saham yang memiliki nilai $\mathrm{ERB}<\mathrm{Ci}^{*}$.

\footnotetext{
${ }^{19}$ J. Edwin |Elton, dan J Martin Gruber, Opcit hal 75

${ }^{20}$ Mao, T.C. James, Essentials of Portfolio Diversification Strategy, The Journal of Finance 2, 1970, hal.111-123

${ }^{21}$ Donald B Trone. dan William R. Allbright. The Producerally Prudent Investment Process, Journal Abstract of Asset Prentice Hall, 1996, hal..53-58
} 


\section{METODE PENELITIAN}

Gambaran singkat dari objek penelitian mengkaji perusahaan-perusahaan yang menjadi populasi penelitian yang terdiri dari 44 perusahaan yang sahamnya masuk dalam jajaran JII. Dari 44 perusahaan tersebut setelah diamati selama 30 kali pengamatan periode bulanan dari Juli 2005 sampai dengan Desember 2007 ternyata terdapat 19 perusahaan yang sahamnya senantiasa muncul dalam JII secara terus menerus selama pengamatan obyek penelitian tersebut. Perusahaan inilah yang kemudian akan dianalisis dengan Model Indeks Tunggal untuk menentukan saham-saham yang memiliki nilai ERB $>\mathrm{Ci}^{*}$ dan saham-saham yang memiliki nilai ERB $<\mathrm{Ci}^{*}$

Langkah-langkah Model Indeks Tunggal dilakukan dengan menghitung ERB (Excess Return to Beta) dan menghitung Cut off Rate dari saham-saham tersebut kemudian dibandingkan antara ERB dengan Cut off Rate-nya. Investasi pada saham-saham yang ERBnya lebih besar daripada Cut off Rate-nya akan memperoleh return lebih tinggi dengan risiko lebih rendah jika dibandingkan dengan investasi pada aset bebas risiko, sedangkan investasi pada saham-saham yang ERB-nya lebih kecil daripada Cut off Rate-nya akan memperoleh return lebih rendah dengan risiko lebih tinggi dibandingkan dengan investasi pada aset bebas risiko.

Dari perhitungan menggunakan SPSS 15 dapat diketahui terdapat investor mengalokasikan dananya pada ke-11 saham yang memiliki ERB > $\mathrm{C}_{\mathrm{i}}^{*}$ dengan proporsi penanaman saham sebesar 8,01\% untuk saham PT. Astra International (ASII), 6,82\% untuk saham PT. Bakrie \& Brothers (BNBR), 17,85\% untuk saham PT. Bumi Resources (BUMI), 9,41 \% untuk saham PT. Indofood Sukses Makmur (INDF), 5,72\% untuk saham PT. Indosat (ISAT), 6,98\% untuk saham PT. Medco Energy International, 16,18\% untuk saham PT. Tambang Batubara Bukit Asam, 13,55\% untuk saham PT. Telekomunikasi Indonesia (TLKM), 0,54\% untuk saham PT. United Tractors (UNTR), 6,95\% untuk saham PT. Unilever (UNVR), 8,01\% untuk saham PT. International Nickel Ind. (INCO), investor akan memperoleh return keseluruhan dari kombinasi saham-saham/ return portofolio sebesar 6,2\% dengan risiko yang hanya sebesar $0,95 \%$. Dengan kata lain dengan melakukan portofolio berupa penanaman saham pada ke-11 saham tersebut dengan proporsi pendanaan seperti yang disebutkan di atas, investor telah mendapatkan return yang optimal dibandingkan berinvestasi pada aset bebas risiko seperti deposito. Penelitian ini merupakan penelitian kausalitas, yang menggunakan data sekunder berupa saham-saham yang tergabung dalam Jakarta Islamic Indeks (JII) di Bursa Efek Indonesia (BEI). Obyek penelitian yang diamati sebanyak 44 emiten yang listed pada Jakarta Islamic Index (JII) di Bursa Efek Indonesia (BEI) yang muncul terus menerus selama 30 kali. Sedangkan teknik analisis yang digunakan adalah model indeks tunggal dan uji Mann-Whitney

\section{PEMBAHASAN}

Rata-rata volume perdagangan saham-saham yang memiliki nilai $\mathrm{ERB}>\mathrm{Ci}^{*}$ dan saham-saham yang memiliki nilai ERB $<\mathrm{Ci}^{*}$ dapat dilihat pada tabel I.

Tabel 1 Perbandingan Rata-rata Volume Perdagangan Saham-saham yang Memiliki ERB $>C_{i}^{*}$ dan Rata-rata Volume Perdagangan Saham-saham yang Memiliki ERB $<C_{i}^{*}$

\begin{tabular}{|c|c|c|}
\hline Pengamatan & ERB $>\mathrm{C}_{\mathrm{i}}^{*}$ & ERB $<\mathrm{C}_{\mathrm{i}}^{*}$ \\
\hline 1 & 1.136 .468 & 267.370 \\
\hline 2 & 1.228 .849 & 330.806 \\
\hline 3 & 831.437 & 237.359 \\
\hline 4 & 1.152 .428 & 203.563 \\
\hline 5 & 522.756 & 139.188 \\
\hline 6 & 660.969 & 235.274 \\
\hline
\end{tabular}




\begin{tabular}{|c|c|c|}
\hline 7 & 731.102 & 308.337 \\
\hline 8 & 780.848 & 291.638 \\
\hline 9 & 1.706 .897 & 235.042 \\
\hline 10 & 933.088 & 372.963 \\
\hline 11 & 1.768 .474 & 622.129 \\
\hline 12 & 781.348 & 175.490 \\
\hline 13 & 588.145 & 174.819 \\
\hline 14 & 610.373 & 223.415 \\
\hline 15 & 672.906 & 275.044 \\
\hline 16 & 592.369 & 268.707 \\
\hline 17 & 752.473 & 294.868 \\
\hline 18 & 865.646 & 260.159 \\
\hline 19 & 1.208 .773 & 348.550 \\
\hline 20 & 1.135 .066 & 225.326 \\
\hline 21 & 855.242 & 249.040 \\
\hline 22 & 933.913 & 387.897 \\
\hline 23 & 1.454 .504 & 435.269 \\
\hline 24 & 1.174 .083 & 339.012 \\
\hline 25 & 1.491 .485 & 354.024 \\
\hline 26 & 1.604 .437 & 420.856 \\
\hline 27 & 1.001 .460 & 340.751 \\
\hline 28 & 1.354 .494 & 593.532 \\
\hline 29 & 1.340 .024 & 766.464 \\
\hline 30 & 698.042 & 331.085 \\
\hline
\end{tabular}

Sumber : data penelitian diolah

Setelah melakukan pengelompokan antara perusahaan-perusahaan yang masuk kandidat portofolio dan yang bukan kandidat portofolio, maka langkah selanjutnya adalah menguji hipotesis untuk menguji rata-rata volume perdagangan antar saham-saham yang masuk kandidat portofolio optimal dengan yang bukan kandidat portofolio optimal.

Sebelum melakukan pengujian hipotesis dilakukan uji normalitas data menggunakan Kolmogorov-Smirnov Test dengan koreksi Liliefors, terbukti dari hasil analisis data yang digunakan tidak terdistribusi normal $(0,001<0,05)$. Hasil uji normalitas data menggunakan Kolmogorov-Smirnov test dengan koreksi Liliefors dapat dilihat pada tabel 2.

Tabel 2 Uji Kolmogorov-Smirnov dengan Koreksi Liliefors Tests of Normality

\begin{tabular}{|l|l|l|l|l|l|l|}
\hline & \multicolumn{3}{|c|}{ Kolmogorov-Smirnov(a) } & \multicolumn{3}{c|}{ Shapiro-Wilk } \\
\hline & Statistic & df & Sig. & Statistic & \multicolumn{1}{c|}{ Df } & Sig. \\
\hline Rata2 &, 157 & 60 &, 001 &, 898 & 60 &, 000 \\
\hline
\end{tabular}

Sumber: data penelitian diolah

Uji normalitas menggunakan Uji Kolmogorov-Smirnov dengan koreksi Liliefors. Hasil uji normalitas data menunjukkan $\alpha=0,001$ berarti data bersifat tidak normal. Karena lebih kecil dari $\alpha=0,05$ sehingga uji hipotesis menggunakan uji statistik Mann-Whitney. Pada pengujian hipotesis ini terdiri dari dua sampel yang bebas satu dengan yang lain, yaitu rata-rata volume perdagangan saham-saham yang memiliki nilai $\mathrm{ERB}>\mathrm{Ci}^{*}$ dan rata-rata volume perdagangan saham-saham yang memiliki nilai ERB $<\mathrm{Ci}^{*}$

Hasil pengujian hipotesis dengan menggunakan Man-Whitney menunjukkan bahwa Asymp-Sig ( 2 tailed/Asymtotic Significance adalah 0,000 atau probabilitas di bawah 0,05 
$(0,000<0,05)$. Sehingga atas analisa tersebut Ho ditolak. Hal ini menunjukkan bahwa dua hal yang diuji tersebut yaitu rata-raata volume perdagangan saham-saham yang memiliki nilai $\mathrm{ERB}>\mathrm{Ci}^{*}$ dengan rata-rata volume perdagangan saham-saham yang memiliki nilai ERB < $\mathrm{Ci}^{*}$ berbeda secara signifikan, sehingga hipotesis penelitian ini diterima atau terdapat rasionalitas investor dalam pemilihan saham-saham yang tergabung pada JII di BEI. Hasil uji statistic Man-Whitney dapat dilihat pada tabel 3.

Tabel 3 Mann-Whitney Test NPar Tests Ranks

\begin{tabular}{|l|l|l|l|l|}
\hline & Kelompok & $\mathrm{N}$ & Mean Rank & Sum of Ranks \\
\hline Rata2 & ERB $>\mathrm{Ci}$ & 30 & 44,97 & 1349,00 \\
\hline & ERB $<\mathrm{Ci}^{*}$ & 30 & 16,03 & 481,00 \\
\hline & Total & 60 & & \\
\hline
\end{tabular}

Sumber: data penelitian diolah

Hasil pengujian hipotesis dengan menggunakan Mann-Whitney menunjukkan AsympSig ( 2 tailed/Asymtotic Significance) atau probabilitas di bawah $0,05(0,000<0,05)$. Hal ini berarti Ho yang menyatakan tidak terdapat perbedaan yang signifikan antara rata-rata volume perdagangan saham-saham yang memiliki nilai $\mathrm{ERB}>\mathrm{Ci}^{*}$ dengan rata-rata volume perdagangan saham-saham yang memiliki nilai ERB $<\mathrm{Ci}^{*}$ ditolak. Dengan demikian $\mathrm{H} 1$ yang menyatakan adanya perbedaan yang signifikan antara rata-rata volume perdagangan saham-saham yang memiliki nilai $\mathrm{ERB}>\mathrm{Ci}^{*}$ dengan rata-rata volume perdagangan sahamsaham yang memiliki nilai $\mathrm{ERB}<\mathrm{Ci}^{*}$ diterima.

Dari hasil olah data yang berhasil dikumpulkan telah dihitung rata-rata total volume perdagangan saham-saham yang memiliki nilai ERB > Ci* selama 30 kali pengamatan adalah sebesar 1.018.937, sedangkan rata-rata total volume perdagangan saham-saham yang memiliki nilai ERB < Ci* selama 30 kali pengamatan adalah sebesar 323.599, ada perbedaan dari keduanya sebesar 695.338. Sesuai dengan hasil uji Mann-Whitney, perbedaan ini adalah nyata/signifikan.

Adanya perbedaan signifikan antara rata-rata volume perdagangan saham antara perusahaan yang memiliki nilai $\mathrm{ERB}>\mathrm{Ci}^{*}$ dengan rata-rata volume perdagangan perusahaan yang memiliki nilai $\mathrm{ERB}<\mathrm{Ci}^{*}$ menunjukkan perilaku investor yang rasional yang lebih memilih membeli saham-saham yang memiliki nilai $\mathrm{ERB}>\mathrm{Ci}^{*}$.

Hasil penelitian ini sama dengan penelitian dari R. Agus Sartono dan Sri Zulaihati (1998), yang melakukan penelitian tentang rasionalitas investor dalam pemilihan sahamsaham pada ILQ-45 di BEJ. Hasil penelitiannya menemukan bukti empiris bahwa terdapat perbedaan yang signifikan antara rata-rata volume perdagangan saham yang memiliki nilai $\mathrm{ERB}>\mathrm{Ci}^{*}$ dengan rata-rata volume perdagangan saham yang memiliki nilai ERB $<\mathrm{Ci}^{*}$. Hal itu menunjukkan terdapat rasionalitas investor dalam pemilihan saham-saham yang tergabung dalam ILQ-45 di BEJ.

Persamaan tersebut menunjukkan bahwa perilaku investor yang rasional tidak dipengaruhi oleh pengelompokan indeks saham baik syari'ah maupun non syari'ah. Investor akan lebih sering membeli saham yang memiliki ERB tinggi tanpa melihat apakah saham yang dibelinya termasuk saham syari'ah atau bukan.

Sedangkan hasil penghitungan risiko dan return portofolio dengan model indeks tunggal pada penelitian ini menunjukkan bahwa saham yang masuk sebagai faktor penghitung JII telah menjamin tercapainya harapan investor akan perolehan return yang diinginkannya, yaitu return portofolio sebesar 6,2\% dengan risiko ( $\sigma p)$ sebesar $0,95 \%$. Hasil penelitian ini berbeda dengan penelitian sebelumnya yang dilakukan oleh R. Agus Sartono dan Sri 
Zulaihati $^{22}$ yang menunjukkan bahwa saham yang masuk sebagai faktor penghitung ILQ-45 belum menjamin tercapainya harapan investor akan perolehan return yang diinginkannya, yaitu return portofolio sebesar $2,73 \%$ dengan risiko $(\beta p)$ sebesar $271,38 \%$.

Perbedaan tersebut terjadi karena saham-saham yang masuk sebagai faktor penghitung JII memiliki perbedaan syarat-syarat pengelompokannya dengan saham-saham ILQ-45. Saham-saham yang akan diikutkan sebagai penghitung indeks JII memiliki ketentuan tidak boleh untuk digunakan dalam aktivitas spekulasi atau perjudian, dan harus konsisten berkapitalisasi besar selama satu tahun terakhir. Hal inilah yang menyebabkan saham-saham JII memiliki return portofolio dan risiko yang lebih baik dibandingkan dengan saham-saham ILQ-45.

\section{PENUTUP}

Tujuan dari penelitian ini adalah untuk menentukan ada tidaknya rasionalitas investor dalam melakukan pemilihan saham untuk membentuk portofolio optimal dengan model indeks tunggal. Beberapa kesimpulan yang dapat ditarik dari penulisan ini adalah

Obyek penelitian yang diamati sebanyak 44 emiten yang listed pada Jakarta Islamic Index (JII) di Bursa Efek Indonesia (BEI) yang muncul terus menerus selama 30 kali pengamatan sebanyak 19 emiten. Dari 19 emiten tersebut yang memiliki nilai ERB> Ci* sebanyak 11 emiten yaitu Astra International, Bakrie \& Brothers, Bumi Resources, Indofood Sukses Makmur, Indosat, Medco International, Tambang Batubara Bukit Asam, Telekomunikasi Indonesia, United Tractors, Unilever Indonesia, International Nickel Ind. Uji KolmogorovSmirnov dengan koreksi Liliefors menunjukkan tingkat signifikansi 0,001 atau probabilitas di bawah $0,05(0,001<0,05)$ yang berarti data bersifat tidak normal. Hasil Pengujian hipotesis dengan uji statistik non parametrik Mann-Whitney Test menunjukkan Asymp-Sig (2 tailed/Asymtotic Significance sebesar 0,000 atau probabilitas di bawah 0,05 $(0,000<0,05)$. Sehingga atas analisa tersebut Ho ditolak. Hal ini menunjukkan bahwa dua hal yang diuji tersebut yaitu rata-rata volume perdagangan saham-saham yang memiliki nilai ERB> Ci* dengan saham-saham yang memiliki nilai $\mathrm{ERB}<\mathrm{Ci}^{*}$ berbeda secara signifikan, sehingga hipotesis penelitian ini diterima atau terdapat rasionalitas investor dalam pemilihan saham pada JII dengan model indeks tunggal di BEI.

Penelitan ini telah menunjukkan adanya rasionalitas investor dalam memilih sahamsaham yang tergabung dalam Jakarta Islamic Index (JII). Investor tetap memilih membeli saham Jakarta Islamic Index (JII) yang memiliki return lebih besar daripada tingkat suku bunga deposito SBI. Saham-saham Jakarta islamic Index (JII) yang return-nya lebih kecil dari tingkat suku bunga deposito SBI tidak akan diminati oleh investor.

Adapun keterbatasan dalam penelitian ini adalah variabel-variabel penelitian yang digunakan dari data sekunder yang sifat pelaporannya bulanan. Aset bebas risiko yang digunakan sebagai pembanding dengan investasi saham di JII hanya satu jenis risk free asset saja yaitu tingkat suku bunga deposito SBI. Adanya keterbatasan dalam penelitian ini, maka untuk selanjutnya penulis memberikan saran-saran antara lain data sekunder yang digunakan sebagai bahan penelitian sebaiknya dari laporan berkala harian atau mingguan, sehingga lebih tepat mewakili variable-variabel yang diteliti. Untuk menambah preferensi investor dalam berinvestasi sebaiknya juga memasukkan aset bebas risiko yang lain seperti investasi emas di pasar berjangka, simpanan dalam bentuk e-gold, dan e-dinar. Penelitian ini dapat digunakan oleh investor sebagai salah satu acuan guna pengambilan keputusan di BEI.

\footnotetext{
${ }^{22}$ R. Agus Sartono dan Sri Zulaihati, 1998, Rasionalitas Investor Terhadap Pemilihan dan Penentuan Portafolio Optimal Dengan Model Indeks Tunggal di BEJ. Kelola No. 17/VII/1998, hal 32-33.
} 


\section{DAFTAR PUSTAKA}

Bawazier, Said dan Sitanggang, (1994), Memilih Saham-Saham untuk Portofolio Optimal, Jurnal Usahawan Vol. XI, hal 34-40. Januari.

Bringham, F. Eugene dan Gapenski C. Louis, (1993), Intermediate Financial Management, New York , Harcourt Brace College.

Elton , J. Edwin, dan J Martin Gruber, (1995), Modern Portofolio Theory and The Investment Analisys. New York, John Wiley \& Sons. Inc.

Fauzi,Ahmad Johan Arifin, dan M. Fakhrudin (2004), Aplikasi Excel dalam Finansial Terapan, Jakarta, PT. Elex media Komputindo.

Husnan, Suad, (2001), Dasar-dasar Teori Portofolio, Yogyakarta : UPP AMP YKPN.

Manurung, Adler Haymans, (1997), Kapitalisasi Besar, Kecil, dan Campuran, Jurnal Usahawan, No. 12 Th XXVI Desember.

Mao, T.C. James, (1970), Essentials of Portfolio Diversification Strategy, The Journal of Finance 2.

Markowitz, M. Harry,(1959), Portofolio Security : Efficient Diversification of Investment, New York: John Wiley \& Sons. Inc.

Poon, S, S.J. Taylor dan C.W.R. Ward (1992), Portofolio Diversification: A Pictorial Analysis of the U.K. Stock market, Journal of Business Finance and Accounting.

Sartono, R. Agus, \& Sri Zulaihati, (1998), Rasionalitas Investor Terhadap Pemilihan dan Penentuan Portafolio Optimal Dengan Model Indeks Tunggal di BEJ. Kelola No. 17/VII/1998

Sartono, R. Agus, \& Sri Zulaihati, (1998), Rasionalitas Investor Terhadap Pemilihan dan Penentuan Portafolio Optimal Dengan Model Indeks Tunggal di BEJ. Kelola No. 17/VII/1998

Sharpe R. William F. Gordon J. Alexender, dan Jeffry V. Bailey, (1963), Investment. New York : Prentice Hall.

Trone, Donald B. dan William R. Allbright (1996), The Producerally Prudent Investment Process, Journal Abstract of Asset, Prentice Hall, hal..53-58

Van Horne. James C \& John Wachowitz Jr., (1992), Financial Management and Policy, Englewood: Prentice Hall. 
